\title{
Impact of Macroeconomic Policies on the Ghana Stock Exchange: A Cointegration Analysis
}

\author{
Samuel Antwi ${ }^{1,2}$, Xicang Zhao $^{1} \&$ Ebenezer Fiifi Emire Atta Mills ${ }^{3}$ \\ ${ }^{1}$ School of Finance and Economics, Jiangsu University, Zhenjiang, Jiangsu, China \\ ${ }^{2}$ Koforidua Polytechnic, Koforidua, Ghana \\ ${ }^{3}$ School of Business Administration, Jiangsu University, Zhenjiang, Jiangsu, China \\ Correspondence: Samuel Antwi, School of Finance and Economics, Jiangsu University, 301 Xuefu Road, \\ Zhenjiang, Jiangsu, China. Tel: 86-189-1282-3943. E-mail: samyantwi@yahoo.com
}

Received: December 6, 2012

Accepted: December 25, 2012

Online Published: January 25, 2013

doi:10.5539/ibr.v6n3p100

URL: http://dx.doi.org/10.5539/ibr.v6n3p100

\begin{abstract}
The study examined the impact of fiscal and monetary policy actions on the stock market in Ghana. In pursuing this, the researchers probed the inter-temporal interaction between macroeconomic policies and stock market activities in Ghana and investigated the efficiency of the stock market with respect to fiscal and monetary policy information. It was found that, both from common correlation analysis to recent econometric modeling; indicate fiscal policy actions have significant effects on stock market activities and not the other way round. In addition, there is a unidirectional causal effect of fiscal policy actions on stock market activity. It was thus concluded that the fiscal policy actions do matter in the activities of the stock market. The study recommends that government must synchronize its fiscal policy actions with activities in the stock market among others.
\end{abstract}

Keywords: Ghana Stock Exchange, fiscal policy, monetary policy, inflation, cointegration

\section{Introduction}

There is substantial theoretical evidence from the Keynesian paradigm that fiscal or monetary policy actions cannot separately achieve desirable macroeconomic objectives. Hence a policy mix, where some suitable level of fiscal policy is accompanied by another suitable level of monetary policy, is emphasized. While there is equally irresistible empirical evidence about this Keynesian proposition, the inter-relations between fiscal and monetary policy actions and interest rates from the typical IS-LM framework suggest analysis of stock market activities cannot be completely independent of such policy influences. This is the case as changes in any of the fiscal or monetary policy instruments (like government spending, taxes and money supply) change market interest rates instantaneously in the framework and forces investors to evaluate their portfolio. It may be more appropriate to examine the influences of all these policies concurrently when analyzing stock market activity. Unfortunately, this has not been the case in the literature, at least for the developed world. Attempts at analyzing stock market activities considered fiscal policy actions separately from monetary policy actions for obvious reasons (one being the underlying theoretical literature). Relatively few studies have attempted to combine both policies to examine how such policy actions interact intertemporally with stock market activities. The evidence is not different for developing countries. For instance, no study could be found for the case of Ghana, where an attempt is made to analyze stock market activities intertemporally with fiscal and monetary policy actions.

However, such a focus is crucial both from a theoretical and an empirical point of view. From an empirical point of view, a policy mix builds investor confidence and motivates investor decisions. It is thus the purpose of this study to investigate the extent to which stock prices (or returns) incorporate all publicly available information on fiscal and monetary policy actions in Ghana.

This was done by using quarterly time series data between 1990 and 2010 and employing a cointegration and causality test procedures on the above stated relation.

\subsection{Literature Review}

The issue about whether government fiscal deficits have any effect on stock market activity has been a topical issue among financial economists. While some argued that fiscal policy actions have no effect on stock market 
activity due to the efficiency of stock markets, others disagree, and insisted that fiscal deficits may affect stock market activity through changes in the rate of interest which triggers a portfolio revaluation by investors. The former view is referred to as the Ricardian equivalence proposition attributed to Barro (1974). The Ricardian equivalence view is supported by stock market efficiency (SME) hypothesis. In its semi strong form, the SME hypothesis contends that stock prices fully reflect all publicly available information (Fama, 1970; 1991; Davidson \& Froyen, 1982).

Contrary to the Ricardian equivalence proportion and SME argument, Tobin (1969) and Blanchard (1981) among others found that fiscal policy actions do matter in relation to the stock market. In his general equilibrium approach, Tobin (1969) asserted that stock returns links the real and the financial sectors of the economy and depicted how budget deficits and the growth of money could have important effects on stock returns. Increases in taxes with government expenditure unchanged would lower asset returns (or prices) due to the fact that such a policy action may put off investors from investing more in the capital market (Laopodis, 2008). Moreover, government fiscal policy in relation to capital gains tax has some implication for the stock market. Investors will only pay capital gains taxes as they offload their shares to other prospective investors. Thus high capital gain taxes may discourage investors from actively trading their shares which may dampen the liquidity of the stock market.

Besides increases in government borrowing would lead to a rise in the short term interest rates. This may culminate in a decline in stock market activity due to lower expected returns. However, with respect to high interest rate, which threatens to crowd out the private sector culminating in a decline in investment and economic activity, the central bank may take action by increasing the money supply. Moreover, Blanchard (1981) argues that fiscal policy may be motivated by other economic and political considerations. Thus, certain fiscal policy measures may be unanticipated by economic agents and therefore can be described as a fiscal policy shocks which may affect stock market returns. Even when fiscal policy action is anticipated by economic agents, it may still have some effect on stock market activity due to lags in policy. Two main lags, the decision lag and the implementation lag may account for this development. The decision lags, refers to the time it takes policy makers to effect a change in policy in response to shocks while implementation lags constitute the time it takes for policy changes to be implemented.

There is some disagreement among financial economists on the neutrality of monetary policy on the stock market. Boudoukh, Richardson, and Whitelaw (1994) asserted that whether monetary policy affects the real economy, and whether its effects are quantitatively important, is an empirical question. In economic literature, the effect of monetary policy on stock market returns is analyzed from two main channels, namely through the money supply or the interest rate (prime rate). A change in the money supply for example may lead to changes in market interest rates which would trigger a portfolio readjustment by investors. This may be explained by the fact that, changes in the market interest rate affects the value of wealth - the sum discounted future cash flows (and /or dividends) - thereby compelling investors to evaluate their portfolio. Thus, monetary policy may impact on stock market activity through valuation of physical assets relative to their replacement cost (Tobin, 1969). In his seminal work entitled, "A General Equilibrium Approach To Monetary Theory" Tobin (1969) emphasized stock returns as an important link between the real and financial sides of the economy. In that model, Tobin depicted how stock returns may respond to changes in the monetary and fiscal policy variables of the model. Rozeff (1974) tested the efficient market hypothesis against what he termed the "predictive monetary portfolio model". Developed by Bruner (1961), Friedman (1961) and Friedman and Schwartz (1963), among others, the monetary portfolio model views money as any other asset in the portfolio of investors. Monetary policy shocks will then trigger substitution money and other assets in an attempt to restore their desired money holdings. But it is important to know that investors will respond with a lag, which would imply that money could help predict stock market returns. The findings from Rozeff's (1994) study showed that lagged money supply do not predict future movements in stock prices. However Rozeff argued that, publication lag must be accounted for to find out precisely the particular time that the money supply information is made available to investors. On the contrary his findings lend credence to the fact that stock returns are related to contemporaneous and future changes in the money supply. Rogaslki and Vinso (1997) improved Rozeff's (1974) study by synchronizing the money supply data and ensured that money supply data is generated at the same interval as stock return data by accounting for autocorrelation. The findings from their study indicated that there is a unilateral causality running from stock prices to money supply but not the other way round. Blanchard (1981) analyzed the interaction of output and policy actions on the stock market. He argued that the effect of a change either in current or anticipated policy is a discrete change in the stock market due to the change in the anticipated sequence of profits and real interest rates. According to him, the stock market is not the "cause" of the increase in output, no more than the increase 
in output is the cause of the initial stock market change. They are both the results of changes in policy. Blanchard (1981) further argued that whether policies are anticipated or not is important; the announcement itself will usually lead to a change in anticipated profits and discount rates, leading to a change in the stock market. Under plausible assumptions, the announcement of an expansionary fiscal policy may have a perverse effect, decreasing output before the actual implementation of the policy.

\section{Methodology}

\subsection{The Theoretical Framework}

The discussion so far emphasized an inter-relation between fiscal and monetary policy actions and stock market activities through interest rates. The argument is that fiscal or monetary policy instruments (like government spending, taxes, money supply and interest rates) change market interest rates instantaneously and forces investors to evaluate their portfolio. Fiscal and monetary policy actions concurrently influence stock market activities.

This concern suggests one may have to employ a dynamic econometric model to examine the intertemporal interaction between macroeconomic policies and capital market activities.

Verbeek (2004) mentions that using a dynamic econometric model facilitates the investigation of dynamic interactions between variables in a special way that avoids the potential problems of spurious (nonsense) regression - a regression that produces a fairly high coefficient of determination, high auto-correlated residuals and highly significant coefficient estimates.

Following Laopodis (2008), the inter-relation between macroeconomic policies and capital market activities in Ghana is examined by using the following indicators respectively: General Government final Consumption expenditure (as a \% of GDP), the average lending rate and the GSE all share index (with the rate of inflation and the excess return on the stock market as control variables). This is specified functionally

$$
G S E=f(G O V, L R)
$$

Where GSE is the Ghana Stock Exchange (measuring stock market activities), GOV is General Government final Consumption Expenditure (measuring fiscal policy) and $L R$ is the average Lending Interest Rate (measuring monetary policy). Taking logarithms of both sides of the equation, we have the following;

$$
\ln G S E_{t}=\beta_{0}+\beta_{1} \ln G O V_{t}+\ln \beta_{2} L R_{t}+\varepsilon_{t}
$$

To estimate the above model, the study makes use of the Cointegration Technique due Johansen and Juselius (1990). The technique is essentially a maximum likelihood estimation procedure that allows one to test both for the short and long run relationship between variables. The starting point of the technique is the generation of a Vector Autoregressive Representation (VAR) of variables under consideration at a particular order and testing a hypothesis about the rank of a generated cointegrating equation. Various tests can be conducted to determine the optimal lag lengths and the number of cointegrating equation of the series under consideration. Later a parsimonious equation (representing the short run relationship of variables under investigation) could be estimated. Although Johansen's methodology is typically used in a setting where all variables in the system are I(1), having stationary variables in the system is theoretically not an issue and Johansen (1995) states that there is little need to pre-test the variables in the system to establish their order of integration. If a single variable is I $(0)$ instead of I(1), this will reveal itself through a cointegrating vector whose space is spanned by the only stationary variable in a model.

To complement the above estimation, the Granger Causality test is implemented between the variables under investigation. Granger causality measures whether one thing happens before another thing and helps predict it and nothing else. Thus if, for instance, one is measuring the causal link between $\mathrm{X}$ and $\mathrm{Y}$, and $\mathrm{X}$ is established to be causing $\mathrm{Y}$, then, changes in $\mathrm{X}$ happens first then followed by changes in $\mathrm{Y}$. Hence, two conditions must be satisfied in this case: (1) $\mathrm{X}$ can help in predicting $\mathrm{Y}$ and the regression of $\mathrm{X}$ on $\mathrm{Y}$ has a big coefficient of determination. (2) Y cannot help in predicting X. The Granger causality test is preceded by the specification of a vector autoregressive model (VAR), where the appropriate lags, stability of the model and its specification must be satisfied. After this the causality test can be concluded.

\subsection{The Econometric Technique}

\subsubsection{Stationarity Test}

Studies involving time series analysis necessarily employ data from the past to quantify historical relationships, such that if the future happens to be like the past, then the historical relationship can be used to forecast the 
future. But if the future happens to be essentially different from the past, then those historical relationships may not be reliable in forecasting the future. Hence it is fundamental that time series variables follow at least a stochastic process and are stationary. For the purposes of this study, the Augmented Dickey-fuller (ADF) test was employed to ascertain if the variables under consideration are stationary or not (have a unit root). Where the variables are found to contain unit roots, the study makes use of the logs followed by the respective number of differences of the variables, until the variable in question becomes stationary.

\subsubsection{Testing for Lag Structure}

One of the challenges in specifying an optimal lag length $(\rho)$ for a model is that if it's chosen lag length is too small, it is possible the model may be mis-specified due to the omission of relevant variables and if too large, it is possible the number of degrees of freedom may be lost. In other words, a model with relatively large number of lags is most likely to produce residuals that approach the white noise process, but might not be parsimonious. On the other hand, a model with smaller lag lengths is more likely to be parsimonious, but might not produce residuals that are random enough to approach a white noise process. The above problem implies that there is the need to select an optimal lag length $\rho$. The Schwartz Bayesian information Criteria (SIC) and the Akaike information Criteria (AIC) are identified in literature as appropriate in selecting optimal lag lengths that produces errors that approach a white noise process, subject to the constraint that the smallest number of lag terms was selected for parsimony. These approaches will jointly be employed to determine the optimal lag length of variables for this study.

\subsubsection{Diagnostic Tests}

As Kramer et al. (1985) recommends, conventional regression output needs to be supplemented by a number of specification tests. A series of tests are performed to support this study. These include testing the residuals for normality, homoscedasticity, and autocorrelation. Also, a test was carried out on coefficient in various models for their significance. Lastly, models were taken through the Ramsey's Reset test, Normality test and Stability tests for parsimony.

\subsection{Measurement of Variables and Their Expected Signs}

\subsubsection{The Ghana Stock Exchange (GSE) All-Share Index}

The GSE All-Share index is the principal stock index for the Ghanaian Stock Exchange. This index is calculated from the values of each of the market's listings and measures the performance of portfolios in the market. Effective 4th January, 2011, the GSE has introduced a new method of calculating closing prices of equities on the market. The closing prices of listed equities are calculated using the volume weighted average price of each equity for every given trading day. There are two indexes: the GSE Composite Index (GSE-CI) and the GSE Financial Stocks Index

\subsubsection{Fiscal Policy Indicator (GOV)}

General Government final Consumption expenditure (as a \% of GDP) is used as the indicator for fiscal policy. From the Keynesian paradigm, a fiscal expansion is in consonance with either an increase in government expenditure or a reduction in taxes. This makes the use of the General Government final Consumption expenditure (as a $\%$ of GDP) more appropriate to measure fiscal policy. It is expect to have a negative impact on stock market activities.

\subsubsection{Monetary Policy Indicator (LR)}

The average real lending rate is used as the basic monetary policy indicator given the current emphasis on inflation targeting by the Bank of Ghana. Though the appropriate interest rate should be the prime rate, its non availability for the entire duration under study and in quarterly series, motivated the use of the average real lending rate. This is, again, the rate at which financial institutions lend to their most credit worth investors or the rate at which they borrow from the central bank. It is expected that the average lending rate will have a negative relationship with the demand for credit.

\subsubsection{Real Expected Rate of Inflation (INF)}

The real expected rate of inflation is measured by the ratio of the consumer price index for two subsequent periods. The CPI is chosen since it is the best measure for adjusting payments to consumers when the intent is to allow consumers to purchase, at today's prices, a market basket of goods and services equivalent to the one that they could have purchased in an earlier period. It is also the best measure to use when one wants to translate retail sales and hourly or weekly earnings into real or inflation-free figures. 


\subsubsection{Excess Market Return}

Excess market return is obtained by deducting the 3-month treasury bills rate from the GSE All-share index. It represents the yield spread between risk free and risky instruments. The higher the yield spread, the more investors are encouraged to invest in equities rather than in short term instruments such as the treasury bills. A positive relationship is expected between excess market returns and stock prices.

\subsection{The Data}

The study employed quarterly time series data for Ghana between 1990 and 2010. The datasets were obtained from the Ghana Statistical Service and the World Development Indicators CD Rom (Africa Edition). Data on the consumer price index and GDP were obtained from the Ghana Statistical Service; while that on the general Government final Consumption expenditure and the lending rate was obtained from the World Development Indicators CD Rom (Africa Edition). The GSE all-share index was obtained from the Ghana Stock Exchange. Since quarterly series are unavailable for some of the variables, disaggregated series were generated with E-Views (5.1).

\section{Empirical Results and Discussion}

\subsection{Data Description}

For estimation purposes, some of the variables were transformed by either taking the natural logs or expressing them as rates and ratios (i.e. in percentages). Given that quarterly time series data of some of these variables are unavailable, disaggregated estimates were obtained with the aid of an econometric software package (E-Views 5.1). The transformation and the new variables are described in Table 1.

Table 1. Transformed time series data

\begin{tabular}{|c|c|c|c|}
\hline Time Series & Denotations & Units & Transformation Type \\
\hline Stock Market Activity & GSE & Logs & Computed as log of the Ghana Stock Exchange-All Share Index \\
\hline Monetary Policy Indicator & LR & $\%$ & Computed as the average of the Lending Interest Rate \\
\hline Fiscal Policy Indicator & GOV & $\%$ & $\begin{array}{l}\text { Computed as the General Government final consumption expenditure as a } \% \\
\text { of GDP }\end{array}$ \\
\hline Excess Return on the Market & EMR & Ratio & $\begin{array}{l}\text { The difference between the GSE-All Share Index and the average Lending } \\
\text { Interest Rate }\end{array}$ \\
\hline Inflation & INF & $\%$ & Computed as the ratio of current CPI and Previous CPI \\
\hline
\end{tabular}

Source: Data from Ghana Stock Exchange and Bank of Ghana.

\subsection{A Formal Unit Root Test}

To ascertain the stationarity status of the variables under investigation, the Augmented Dickey Fuller (ADF) test for unit roots is applied on the selected variables. This test ensured that variables enter the selected VAR model, developed in the previous section, in a non-explosive form and are robust.

Table 2. Results for unit root (ADF and DF-GLS)

\begin{tabular}{lll}
\hline Variable & ADF Statistics & \\
\cline { 2 - 3 } & Level & $1^{\text {st }}$ Difference \\
\hline GSE & $-1.1621(0.6854)$ & $-4.3028(0.0000)$ \\
LR & $-1.1704(0.6821)$ & $-7.1902(0.0000)$ \\
GOV & $-2.1799(0.2156)$ & $-2.3524(0.0192)$ \\
EMR & $-0.8384(0.8007)$ & $-4.1126(0.0001)$ \\
INF & -7.0122 & $\ldots$. \\
\hline
\end{tabular}

Source: Data from Ghana Stock Exchange and Bank of Ghana.

Note: P-values are in parenthesis.

The ADF test statistics are presented in Table 2. These test statistics are compared to the critical values from MacKinnon (1996) to conclude on the stationarity status of the series. As can be learned from the p-values, in Table 2, almost all variables selected for the estimation process were not stationary on their levels, with the exception of INF - which happened to be stationary on level. This suggests some sought of trending in the variables selected. A more formal test will be to plot the series to examine this trending. 


\subsection{Descriptive Statistics for Selected Variables}

Table 3 contains some descriptive statistics for the indicators of fiscal policy, monetary policy and stock market activity. From the table it can be observed that the variable with the highest average is the indicator for monetary policy. This is followed by the indicator for fiscal policy and last, the indicator for stock market activity. It can also be observed that the indicator for stock market activity has the lowest standard deviation; with the indicator for fiscal policy and monetary policy following in an ascending order respectively. This confirms the above claim that the indicator for monetary policy has been exhibiting some intermittent swings. The correlations among the three indicators range from 0.01389 to 1.000 with the correlation between the indicator for fiscal policy and stock market activity being the highest (pairwise).

Table 3. Descriptive statistics for selected variables

\begin{tabular}{llll}
\hline & LGSE & GOV & LR \\
\hline Mean & 6.500204 & 12.31581 & 34.73531 \\
Median & 6.699419 & 12.12168 & 34.24500 \\
Maximum & 8.86013 & 17.50280 & 47.75000 \\
Minimum & 4.055257 & 7.82720 & 23.75000 \\
Std.Dev. & 1.43993 & 2.90367 & 6.98105 \\
Skewness & -0.04952 & 0.00422 & 0.26771 \\
Kurtosis & 2.15509 & 1.96350 & 1.88845 \\
Jarque-Bera & 1.929807 & 2.73076 & 4.05924 \\
Probability & 0.38103 & 0.25528 & 0.13138 \\
Sum & 416.013 & 751.2645 & 2223.06 \\
Sum square Dev. & 130.6241 & 505.8789 & 3070.306 \\
\hline
\end{tabular}

Source: Data from Ghana Stock Exchange and Bank of Ghana.

Fortunately, the correlation between the indicator for stock market activity and monetary policy is negative and weak. This suggests the numerous financial sector liberalization programs aimed at reversing the financial repressive state of the financial sector of Ghana has succeeded in an enabling macroeconomic environment for the financial market and particularly the capital market.

\subsection{Cointegration Test for the Intertemporal}

For a lag length of 2 (selected by Akaike Information Criteria - AIC), there was no evidence of a cointegrating relation between variables selected (See Table 4). Both the trace and the eigen values selected no cointegrating equations. Thus estimations were done without an error correction term.

Table 4. Cointegration test for the intertemporal

\begin{tabular}{llllll}
\hline Data Trend & None & None & Linear & Linear & Quadratic \\
\hline Test Type & No Intercept & Intercept & Intercept & Intercept & Intercept \\
& No Trend & No Trend & No Trend & Trend & Trend \\
Trace & 0 & 0 & 0 & 0 & 0 \\
Max.Eig & 0 & 0 & 0 & 0 & 0 \\
\hline
\end{tabular}

Note: * Critical values based on MacKinnon-Haug-Michelis.

\subsection{Vector Autoregression Estimates}

Table 5 presents the results of the vector autoregressive estimates for the study, along with some regression diagnostics. The regression result indicates a mixed short run relationship between fiscal policy actions and stock market activity. Particularly, an increase in government spending immediately increases activities in the stock market, but in the next period this activities decline. On the other hand, monetary policy actions seem not to have any effects on stock market activity and there are no reciprocal interactions between the variables selected.

This result lends credence to the efficient market hypothesis in relation to monetary policy activities in Ghana and it is consistent with the findings by Darrat (1998) and Laopodis (2008). It thus appear fiscal policy actions have important implications for stock market activity in Ghana and not monetary policy actions. It is likely investors in the Ghanaian stock exchange are fully aware of the impact of macroeconomic policies on capital market activity and have fully incorporated this in the pricing of securities. Hence there is no incentive to outwit the market by doing any technical or fundamental analysis and concentrating on monetary policy. The relatively 
young nature of the market cannot be ruled out. While on the average, the number of companies listed on the exchange has been increasing overtime, it still needs to meet certain yardsticks for the market to be comparable to other more advanced stock exchanges where monetary policy actions could easily spark portfolio re-allocations for investors.

Table 5. Vector autoregression estimates

\begin{tabular}{|c|c|c|c|}
\hline & LGSE & GOV & LR \\
\hline \multirow[t]{3}{*}{ LGSE (-1) } & $1.167102 * *$ & -0.00453 & 3.146122 \\
\hline & -0.12345 & -0.32325 & -2.52207 \\
\hline & [9.45438] & {$[-0.01403]$} & [1.24744] \\
\hline \multirow[t]{3}{*}{ LGSE (-2) } & -0.20043 & 0.105006 & -3.10812 \\
\hline & -0.11624 & -0.32325 & -2.52207 \\
\hline & {$[-1.72429]$} & {$[0.34498]$} & {$[-1.30878]$} \\
\hline \multirow[t]{3}{*}{ GOV (-1) } & $0.144991 * *$ & $1.82934 * *$ & -0.79636 \\
\hline & -0.03042 & -0.07965 & -0.62147 \\
\hline & [4.76649] & 22.9661 & {$[-1.28140]$} \\
\hline \multirow[t]{3}{*}{ GOV (-2) } & -0.12366 & $-0.88201 * *$ & 0.309748 \\
\hline & -0.02861 & -0.07491 & -0.58449 \\
\hline & {$[-4.32261]^{* *}$} & {$[-11.77360]$} & [0.52994] \\
\hline \multirow[t]{3}{*}{$\operatorname{LR}(-1)$} & 0.009248 & -0.00832 & 0.773035 \\
\hline & -0.00696 & -0.01824 & -0.14229 \\
\hline & [1.32783] & {$[-0.45619]$} & [5.43290] \\
\hline \multirow[t]{3}{*}{ LR (-2) } & -0.00027 & -0.00832 & -0.02633 \\
\hline & -0.00679 & -0.01778 & -0.13872 \\
\hline & {$[-0.03917]$} & {$[-0.47508]$} & {$[-0.18983]$} \\
\hline \multirow[t]{3}{*}{$\mathrm{C}$} & -0.29446 & 0.57357 & 12.60116 \\
\hline & -0.25026 & -0.65532 & -5.11291 \\
\hline & {$[-1.17662]$} & {$[0.87525]$} & [2.46458] \\
\hline \multirow[t]{3}{*}{ INF } & -0.0009 & 0.00307 & $0.07296^{* *}$ \\
\hline & -0.00133 & -0.00348 & -0.02714 \\
\hline & {$[-0.67765]$} & [0.88349] & [2.68856] \\
\hline \multirow[t]{3}{*}{ EMR } & $1.61 \mathrm{E}-06$ & $-3.62 \mathrm{E}-05$ & $3.30 \mathrm{E}-05$ \\
\hline & $-2.50 \mathrm{E}-05$ & $-6.60 \mathrm{E}-05$ & -0.00051 \\
\hline & {$[0.06441]$} & {$[-0.55222]$} & [0.06445] \\
\hline R-Squared & 0.993283 & 0.990646 & 0.895839 \\
\hline Adjusted R-Squared & 0.992208 & 0.989149 & 0.879173 \\
\hline F-Statistic & 924.169 & 661.9055 & 53.75331 \\
\hline
\end{tabular}

Source: Data from Ghana Stock Exchange and Bank of Ghana.

\subsection{Granger Causality Tests}

To harmonize the findings in the previous section, a Granger causality test is conducted between the indicators for fiscal policy, monetary policy and stock market activity. The result for the Granger causality test is presented in Table 6.

Table 6. Granger causality tests

\begin{tabular}{llll}
\hline Pairwise Granger Causality Tests & & & \\
\hline Null Hypothesis & Obs. & F-Statistic & Probability \\
\hline GOV does not Granger cause LGSE & 57 & 4.99861 & 0.00189 \\
LGSE does not Granger cause GOV & & 0.87781 & 0.48426 \\
LR does not Granger cause LGSE & 60 & 0.54607 & 0.70266 \\
LGSE does not Granger cause LR & & 1.68135 & 0.16869 \\
LR does not Granger cause GOV & 57 & 1.44485 & 0.23377 \\
GOV does not Granger cause LR & & 2.14165 & 0.09002 \\
\hline
\end{tabular}

Source: Data from Ghana Stock Exchange and Bank of Ghana. 
The result suggests the fiscal policy actions (GOV) do granger cause stock market activity. More also, it was observed that the fiscal policy actions (GOV) does granger cause monetary policy actions (LR). Strangely, these variables were established to be insignificant in the previous section. One important conclusion from this section that complements results from the previous section is that fiscal policy actions are crucial for stock market activity in Ghana. Hence investors in the market should incorporate such actions in the pricing of securities to eliminate all inefficiencies in the market to build investor confidence.

\section{Conclusion}

The study examined the intertemporal interaction between fiscal policy, monetary policy and stock market activity in Ghana. This is in line with theoretical contention of the Keynesian economics that a policy mix of fiscal and monetary policy is the best in achieving macroeconomic objectives. Though this proposition is supported by a number of empirical evidences and sounds great, its interaction with interest rates suggest such policies may have a concurrent effect on stock market activities. This is the case as changes in any of the fiscal or monetary policy instruments (like government spending, taxes, money supply and interest rates) change market interest rates instantaneously and forces investors to evaluate their holdings. In that way, stock market activity is either enhanced or disrupted. Thus the study attempted to examine the intertemporal interaction between macroeconomic policies and capital market activity. To accomplish this, vector autoregressive model is developed and estimated. A Granger causality test is also conducted to complement the above estimations. Further, diagnostic tests were carried out to ensure all models satisfy the assumptions of the estimation techniques selected. The results, both from common correlation analysis to recent econometric modeling, indicate fiscal policy actions have significant effects on stock market activities and not the other way round. In addition, there is a unidirectional causal effect of fiscal policy actions on stock market activity. It was thus concluded that the fiscal policy actions do matter in the activities of stock market. Thus such actions should be incorporated in the pricing of securities in the market to eliminate all inefficiencies in the market and build investor confidence.

\section{References}

Barro, R. J. (1974). Are government bonds net wealth? Journal of Political Economy, 82, 1095-1117. http://dx.doi.org/10.1086/260266

Beck, T., Demeriguc-Kunt, A., Levine, R., \& Maksimovic, V. (2000). Financial structure and economic development: Firm, Industry and Country evidence. World Bank policy research Working Paper. Retrieved from http://www.wds.worldbank.org/servlet/WDSContentServer/WDSP/IB/2000/10/13/000094946_0009090531 1346/Rendered/PDF/multi_page.pdf

Bernanke, B., \& Blinder, A. (1988). Credit, Money and Aggregate Demand. American Economic Review, 78(2), 901-21.

Blanchard Olivier, J. (1981). Output, the stock market and interest rates. American Economic Review, 71, $132-43$.

Bordo, M. D., \& Wheelock, D. C. (2004). Monetary Policy and Asset Prices: A Look Back at Past U.S. Stock Market Booms. NBER Working Papers 10704. Retrieved from http://www.nber.org/papers/w10704

Boudoukh, J. M., Richardson, M., \& Whitelaw. (1994). A Tale of Three Schools: Insights on autocorrelation of Short-Horizon stock Returns. Review of Financial Studies, 6, 799-824. http://dx.doi.org/10.1093/rfs/7.3.539

Brunner, K. (1961). A Schema for the Supply Theory of Money. International Economic Review, January, 65-78. http://dx.doi.org/10.2307/2525590

Calderon, C., \& Liu, L. (2002). The Direction of causality between financial development and economic growth. $\begin{array}{lllll}\text { Working } & \text { Paper } & \text { No. } & \text { Retrieved } & \text { from }\end{array}$ http://www.comisiondistorsionesdeprecios.cl/eng/studies/working-papers/pdf/dtbc184.pdf

Copper, R. (1974). Efficient Capital Markets and the Quantity Theory of Money. Journal of Finance, 19, 887-908. http://dx.doi.org/10.2307/2978598

Darrat, A. F. (1988). On fiscal policy and the stock market. Journal of Money Credit and Banking, 20(3), 353-363. http://dx.doi.org/10.2307/1992261

Darrat, A. F., \& Brocato, J. (1994). Stock market efficiency and the federal budget deficit: another anomaly. The Financial Review, 29, 49-75. http://dx.doi.org/10.1111/j.1540-6288.1994.tb00813.x 
Davidson, L. S., \& Froyen, R. T. (1982). Monetary policy and stock returns: are stock markets efficient? Federal Reserve Bank of St. Louis Economic Review, 64, 3-12.

Dickey, D. A., \& Fuller, W. A. (1979). Distributions of the estimators for autoregressive time series with unit root. Journal of American Statistical Association, 74(Pt 1), 427-31. http://dx.doi.org/10.2307/2286348

Fama, E. F. (1990). Stock returns, expected returns and real activity. Journal of Finance, 45(4), 1089-1108. http://dx.doi.org/10.2307/2328716

Fama, E. F. (1991). Efficient Markets II. Journal of Finance, 46(5), 1575-1618. http://dx.doi.org/10.2307/2328565

Friedman, M., \& Schwartrz, A. J. (1963). A Monetary History of the United States. Princeton University Press.

Friedman. (1988). Money and the Stock Market. Journal of Political Economy, 96(2), 221-245. http://dx.doi.org/10.1086/261534

Hamburger, M., \& Kochin, L. (1972). Money and Stock Prices: the Channels of Influence. Journal of Finance Papers and Proceedings, 27, 231-249. http://dx.doi.org/10.2307/2978472

Johansen, S., \& Juselius, K. (1990). Maximum likelihood estimation and inference on cointegration - with applications to the demand for money. Oxford Bulletin of Economics and Statistics, 52, 169-210. http://dx.doi.org/10.1111/j.1468-0084.1990.mp52002003.x

King, R. E., \& Levine, R. (1993). Financial Intermediation and Economic Development. In Colin Mayer \& Xavier Vives (Eds.), Financial Intermediation in the Construction of Europe (pp. 156-189). London: Centre for Economic Policy and Research. http://dx.doi.org/10.1017/CBO9780511752056.011

Kramer, W., Harald, S., Johann, M., \& Peter, H. (1985). Diagnostic checking in practice. REVIEW, 67, 118-123. http://dx.doi.org/10.2307/1928441

Laopodis, N. T. (2006). Dynamic Interactions among the Stock Market, Federal Funds Rate, Inflation, and Economic Activity. The Financial Review, 41(4). http://dx.doi.org/10.1111/j.1540-6288.2006.00155.x

Lee, U. (1997). Stock market and macroeconomic policies: new evidence from Pacific Basin countries. Multinational Finance Journal, 1(2), 273-289.

MacKinnon, J. G. (1996). Numerical Distribution Functions for Unit Root and Cointegration Tests. Journal of Applied Econometrics, 11, 601-618. http://dx.doi.org/10.1002/(SICI)1099-1255(199611)11:6<601::AID-JAE417>3.0.CO;2-T

Rogalski, R., \& Vinso, J. (1977). Stock returns, money supply and the direction of causality. Journal of Finance, 32, 1017-1030. http://dx.doi.org/10.2307/2326509

Rozeff, S. M. (1974). Money and Stock Prices Market Efficiency and The Lag in Effect Of Monetary Policy. Journal of financial Economics, 1, 245-302. http://dx.doi.org/10.1016/0304-405X(74)90020-8

Tobin, J. (1969). A general equilibrium approach to monetary theory. Journal of Money, Credit and Banking, 1, 15-29. http://dx.doi.org/10.2307/1991374

Verbeek, M. (2004). A Guide to Modern Econometrics. England: John Wiley and Sons, Ltd. 